\title{
Research on International Logistics Mode under the Background of Cross-Border E-commerce
}

\author{
Liu Xiang \\ Fuzhou University of International Studies and Trade \\ Fuzhou, Fujian 350202
}

\begin{abstract}
Cross-border e-commerce provides market opportunities for the development of international logistics, and the improvement of international logistics is one of the necessary links in the development of cross-border e-commerce. This paper studies how to solve the problems existing in the logistics industry under the background of cross-border e-commerce and ponders over the future development. By comparing the current transportation mode of the international logistics industry, the existing problems are compared and analyzed. Finally, some innovative ideas of the international logistics mode under the cross-border e-commerce background are obtained finally, which have some reference value for the future planning of the industry.
\end{abstract}

Keywords-International Logistics Mode, Cross-Border Ecommerce; Development Strategy; Influencing Factors

\section{CURRENT SitUATION OF CROSS-BORDER E-COMMERCE}

At present, cross-border e-commerce development in the world has been favored by people of all countries. The implementation process of cross-border e-commerce refers to an international commodity trading activity to complete commodity trading by circulating commodities to the hands of consumers through international logistics, in which the crossborder commodities are traded, paid and settled through ecommerce platform. The cross-border e-commerce is developed on the basis of the computer network technology. From the prospective of current development situation, our country has become the first trading nation. The main reason lies in the main contribution of cross-border e-commerce in it. Compared with the developing mode of traditional international economy, cross-border e-commerce contributes to the international trade of our country much more than that of traditional international trade. Therefore, only constantly innovating and reforming the international logistics mode under the cross-border e-commerce mode and improving the service level of the logistics enterprises can fundamentally improve the work quality of our country's cross-border ecommerce industry.

\section{DEVELOPMENT STATUS OF INTERNATIONAL LOGISTICS}

In the broad sense, international logistics refers to international trade and non-trade logistics, international logistics investment and cooperation, etc.. In the narrow sense, it refers to the logistics service mode that exists in the trading subjects from two different customs areas. For example, at the present stage, the more influential UPS, USPS, Chukou1, 4PX and others belong to the scope of international logistics.

According to the relevant data shows that the volume of international logistics business carried out by our country and the volume of international logistics business carried out internationally are rising steadily from 2010 to 2014; among them, the international logistics volume carried out in China has risen from 5.63 billion kilotons in 2010 to 5.91 billion kilotons in 2014, with an annual increase of $1.22 \%$; and international logistics volume carried out internationally has increased from 14.37 billion kilotons in 2010 to 19.54 billion kilotons in 2014, with an average annual increase of $7.99 \%$. In view of the year-on-year growth rate of domestic and international logistics volume, the international logistics volume carried out in China and year-on-year growth rate fell only in 2011, while growth is kept steady in the rest years. The year-on-year growth rate of international logistics volume in 2010 has also fallen, but the international logistics volume in 2011 is 15.94 billion kilotons, and compared with 14.37 billion kilotons in 2010 , it has increased by 0.43 billion kilotons, which still remains a certain growth trend.

\section{RELATIONSHIP BETWEEN CROSS-BORDER E- COMMERCE AND INTERNATIONAL LOGISTICS}

Cross-border e-commerce and international logistics are two industries which are interrelated and closely linked and cross-border e-commerce provides market opportunities for the development of international logistics, and the improvement of international logistics is one of the necessary links in the development of cross-border e-commerce.

Cross-border e-commerce enterprises bring the market for the development of international logistics. The traditional business mode becomes more and more unable to meet the needs of people. In the new era, consumers will pay more attention to the quality of commodities and the richness of types of commodities. In addition, consumers will pay more attention to the shopping experience, while the emergence of cross-border e-commerce will greatly improve the convenience 
of shopping, meet the needs of consumers and optimize the purchase experience of consumers. At the same time, the emergence of cross-border e-commerce plays a role in improving the quality of enterprise service, increasing the effectiveness of the supply chain, enhancing the efficiency of the enterprise operation, promoting the turnover of international trade and developing scope and so on; so many traditional enterprises introduce the cross-border e-commerce business mode at present, and the huge cross-border ecommerce market will provide market opportunities for the development of "international logistics", the essential link of cross-border e-commerce.

\section{SELECTION OF INTERNATIONAL LOGISTICS MODE OF CROSS-BORDER E-COMMERCE.}

At present, there are more and more cross-border ecommerce manufacturers in various countries. Whether it is for the seller or the buyer, how the commodities are used in the buyer's hands or which mode of transportation is selected to acquire the goods they bought is an important issue. In this case, sellers can be divided into large sellers and small sellers. If it is a relatively small seller, the seller can directly transport the commodities through the network platform or the international general express mode. If it is a large seller, manufacturers should focus on the purchase and sale of commodities, but also on the formation of service of commodities and the entire logistics system. Therefore, in the current development mode of cross-border e-commerce, it is urgent to choose an appropriate and effective mode of international logistics.

\section{A. Mode of Postal Express}

The way of postal express has already formed a relatively complete network all over the world. The development of postal delivery mode has benefited from our country's postal union and Kahala postal organization. But the existing problem is that the number of member countries under the organization is large and the developing modes of the postal delivery of all countries are not consistent and the development of each country is not very balanced, so if all member countries fail to meet certain standards, the mode of postal delivery will not be able to enter the general cross-border international logistics system.

\section{B. International Express Mode}

The convenience of the international express mode is that it can bring efficient logistics speed. Under normal circumstances, commodities can arrive in the hands of consumers within 48 hours. However, such international express can only be applied in developed countries only. Moreover, the cost of this express mode is very high, and it is difficult to be applied in addition to a few developed countries.

\section{Overseas Warehousing Mode}

The overseas warehousing mode refers to the manufacturer's direct establishment of warehouses in various other countries. In this way, once the order is placed, the goods can be shipped directly from the local warehouse. The management and service modes in the process of packaging and delivery have the same standards. The biggest advantage of this logistics mode is that it enables the seller to manage the remote goods and can enable the buyer to receive the commodity services in a short period of time. The choice of overseas warehousing logistics mode plays a leading role in the development of cross-border e-commerce. At the same time, the overseas warehousing logistics mode has completely changed the relationship between the seller and the logistics distribution.

For the selection of international logistics mode under the environment of cross-border e-commerce, whether it is domestic e-commerce or cross-border e-commerce development mode, the selection of logistics is a key link. From the perspective of the development example of ecommerce, the cost involved in logistics is always the biggest cost expenditure of online foreign trade. Choosing the right logistics mode in the development of cross-border e-commerce is a key link to improve the quality of service in the entire logistics process. Considering comprehensively from all angles, strengthening logistics is an important step to improve the service and an effective way to improve the profit. Only when the logistics capacity is promoted can the whole trading cycle be shortened and can the turnover of funds be accelerated. Considering according to the comprehensive factors, crossborder e-commerce sellers choose the logistics mode suitable for different commodities in the selection of the international logistics mode according to the characteristics of their commodities and their specific requirements for logistics. Another factor in consideration is to select the most favorable logistics modes for consumers and sellers according to the different characteristics in the off-season and peak season of commodity sales.

\section{INFLUENCE FACTORS AND STRATEGIES OF THE} DEVELOPMENT OF INTERNATIONAL LOGISTICS MODE UNDER CROSS-BORDER E-COMMERCE LOGISTICS ENVIRONMENT

\section{A. Influence Factors of the Development of International Logistics Mode under Cross-Border E-Commerce Logistics Environment}

1) Lack of Coordination Between Cross-border Ecommerce and International Logistics.

Although there are many kinds of developing modes in international logistics, all kinds of modes have its development drawbacks, resulting in the international logistics being unable to realize the coordination with the cross-border e-commerce; the two new logistics modes, such as the offshore warehouse and the border warehouse, need a large amount of logistics investment fund, but the general enterprises cannot afford it; goods consolidation logistics needs related policy support of the state, but it is still lack of the related legal safeguard; since trade zone or free trade zone is set less, it cannot satisfy the needs of cross-border e-commerce; international logistics line 
also has considerable regional limitation; the fourth party logistics is in the initial stage of development and lack of either technology or talent greatly, which cannot lay the foundation for cross-border e-commerce. Except coordination cannot be realized in the development level, coordination with crossborder e-commerce cannot be realized in the international logistics function and international logistics environment, thus resulting in defects appearing in international logistics, such as high transportation cost, low service level, lack of value-added services, etc., and affecting the development of international logistics and cross-border e-commerce to a certain extent at the same time.

\section{2) International Logistics Laws and Regulations are Not} Sound.

Due to the late start of international logistics in China and inadequate relevant legislative conditions, China lacks special laws and regulations to ensure the normal operation of international logistics. At present, most of the laws and regulations on international logistics are departmental rules and regulations, such as the Rules for Automobile Freight Transportation, Regulations on Railway Freight Transportation, Regulations on the Management of Waterway Transportation and the Detailed Rules for the Implementation of Air Freight Transportation Contract, etc., and these laws and regulations do not aims at ensuring the normal operation of international logistics greatly. Besides, as most of practitioners of our country's international logistics are transferred from freight forwarders of the third party logistics, the legal status of these personnel has changed when they are engaged in international logistics; however, due to the lack of law, the relevant departments do not review the employees' identity clearly, and the practitioners are mixed with the good and bad.

\section{3) Level of International Logistics Transport Capacity is} Limited.

With the development of cross-border e-commerce in recent years, the country has promulgated policies and put into construction in improving the construction of infrastructure and enhancing the logistics transport capacity, but at present, the small scale of our country's international logistics infrastructure construction resulting in the limited logistics transport capacity is still an important obstacle to the development of international logistics. At the same time, this is also the reason why there is a big gap between international logistics carried out in China and international level. For example, in air transportation, there are some problems such as less air route, less air freighter, lack of air transport capacity, and high price of air transport logistics, etc.; in land transportation, the unreasonable planning of railway and highway lines causes difficulties in inland export, affecting land transport capacity and increasing logistics costs to a certain extent; in marine transportation, logistics ports are set up enough and the layout is unreasonable, greatly increasing the transfer cost of international logistics and extending the circulation time of international logistics, all of which reflect the shortage of international logistics infrastructure and the limited transport capacity of our country, and then affect the overall level of international logistics and weaken the international competitiveness of our country's export.
4) International Logistics Talent Reserve is Insufficient.

Because of the slow start of international logistics in China, there is no professional talent that is fully suitable for the development of international logistics enterprises in the current talent market, and most of the international logistics practitioners are mostly transferred from other logistics fields temporarily, so they cannot meet the needs of the current international logistics enterprises. Therefore, talent problem is also one of the important factors that restrict the development of our country's international logistics.

\section{B. Development Strategy of International Logistics Mode under Cross-border E-commerce Environment}

First of all, from the enterprise itself, the coordination between cross-border e-commerce and international logistics is enhanced.

The relationship between international logistics and crossborder e-commerce is mutually promoted and commonly developed. As for the current international logistics operation, there are many aspects of mutual incoordinate conditions with cross-border e-commerce. Among them, one of the most important points is that the development level of international logistics is low resulting in the inefficiency of multiple logistics modes, and thus it is difficult to meet the growing demand of cross-border e-commerce. Therefore, the coordination between the cross-border e-commerce and the international logistics should be enhanced, and the different logistics modes should play its due effect on the international logistics, so as to improve the current situation of the international logistics development.

First of all, the coordination of the two is promoted from the aspects of logistics elements. According to the historical background of the development of cross-border e-commerce and international logistics, the coordination of the two can be strengthened in many aspects, such as strategy, resources and supply chain, etc., so as to reduce the cost of logistics, reduce the time of logistics and improve the circulation efficiency of logistics.

Secondly, coordination is promoted from the aspect of network technology. Receipt of order, sorting, numbering, packing, warehousing, transportation, commodity inspection, customs, distribution, after-sale and others are all necessary links of international logistics, and these links are closely related to cross-border e-commerce enterprises and international logistics enterprises. But for now, due to the complexity of international logistics itself and the lack of network technology application in cross-border e-commerce and e-commerce enterprises, the lack of mutual coordination causes the efficiency of logistics transportation to be reduced to a certain extent. Therefore, for the two enterprises, the network technology is fully used on the whole logistics supply chain, so that the cooperation between the cross-border e-commerce enterprises and the international logistics enterprises should be butted seamlessly. 
Finally, coordination of the two is promoted from the aspect of staff competitiveness. Nowadays, the international logistics talents are still facing a great gap, and when facing this problem, enterprises can adopt the college-enterprise coalition form to aim at cultivating international logistics talents, and introduce excellent international logistics talents from foreign or other enterprises, so as to increase the reserve of international logistics talents fundamentally. At the same time, enterprises also need to improve the existing remuneration mechanism, assessment mechanism, promotion mechanism, incentive mechanism and so on, to fundamentally improve the enthusiasm of employees, retain the existing talents and attract foreign talents.

\section{REFERENCES}

[1] Pang Yan. Research on International Logistics Mode in Cross-Border ECommerce Environment [J]. China Business and Market, 2015, 29(10):15-20.

[2] Shen Ke. Discussion on International Logistics Mode Based on CrossBorder E-commerce Environment [J]. Journal of Commercial Economics, 2016 (14): 61-63.

[3] Chen Xinlei. Several Researches and Discussions on International Logistics Mode under Cross-Border E-commerce Environment [J]. China Market, 2016 (23): 121+128.

[4] Xu Jianqun. Analysis Based on the Cross-Border International Logistics Mode Innovation under E-commerce Environment [J]. China Journal of Commerce, 2016 (10): 128-130. 